\title{
Spontaneous rectus sheath hematoma in patients on anticoagulation therapy
}

\author{
Antikoagülan tedavi altındaki hastalarda spontan rektus kılıfi hematomu
}

\author{
Ahmet DAĞ, ${ }^{1}$ Turkay ÖZCAN, ${ }^{2}$ Özgür TÜRKMENOĞLU, ${ }^{1}$ Tahsin ÇOLAK, ${ }^{1}$ \\ Kerem KARACA, ${ }^{3}$ Hakan CANBAZ, ${ }^{1}$ Musa DİRLIK, ${ }^{1}$ Ramazan SARIBAY ${ }^{1}$
}

\section{BACKGROUND}

This clinical study was conducted to present the clinical features, treatment and outcomes of rectus sheath hematoma ( $\mathrm{RSH})$, which is a complication of anticoagulation therapy that can present as acute abdomen.

\section{METHODS}

Twenty-two spontaneous RSH cases who were on anticoagulation therapy were reviewed. Patient characteristics, anticoagulant therapy form and indications, clinical presentation, radiologic work-up, treatment modalities, recurrence, morbidity, and follow-up data were analyzed.

\section{RESULTS}

The majority of the patients were female (64\%), and the mean age was 60.6 years. All of the patients (100\%) were receiving at least one form of anticoagulation therapy; most $(72 \%)$ were on warfarin therapy. History of coughing was found in $45 \%$ of the cases. The most common presenting signs and symptoms were abdominal pain and mass $(77 \%)$. International normalized ratio (INR) was $>3.0$ in all patients on warfarin therapy. The diagnosis was made by abdominopelvic ultrasonography (US) and computerized tomography (CT). CT showed $100 \%$ sensitivity. The majority of patients $(87 \%)$ were treated conservatively. Three patients $(13 \%)$ were operated and 2 patients $(9 \%)$ died as a result of RSH. Two patients experienced recurrence in one year.

\section{CONCLUSION}

RSH should be suspected in elderly, coughing patients on anticoagulation therapy, who present with clinical manifestations of acute abdomen. Early diagnosis can help to avoid increased morbidity or unnecessary surgical intervention.

Key Words: Acute abdomen; anticoagulation; rectus sheath hematoma.

\section{$\boldsymbol{A M A C}$}

Antikoagülan tedavinin bir komplikasyonu olan ve akut karın kliniği oluşturan rektus kılıfı hematomunun (RKH) klinik özelliklerini, tedavisini ve sonuçlarını sunmayı amaçladik.

\section{GEREC VE YÖNTEM}

Antikoagülan tedaviye bağlı gelişen 22 RKH olgusu incelendi. Olguların klinik özellikleri, antikoagülan tedavinin şekli ve endikasyonları, radyolojik bulgular, tedavi yöntemleri, nüksetme, morbidite ve mortalite bilgileri incelendi.

\section{BULGULAR}

Olguların \%72'si kadın olup, yaş ortalaması 60.6 idi. Tüm olgular (\%100) antikoagülan tedavisinin en az bir türünü, \%72'si varfarin tedavisi almaktaydı. Olguların \%45'inde öksürük hikayesi bulunmuştu. En sık karşılaşılan bulgu ve semptomlar karın ağrısı ve kitleydi (\%77). Varfarin tedavisi gören olgularda INR (International Normalized Ratio) ortalaması 3'ün üstünde bulunmuştu. Tanılar, abdominopelvik ultrasonografi ve bilgisayarlı tomografi (BT) aracılığıyla konuldu, BT \%100 duyarlılık gösterdi. Olguların çoğu (\%87) konservatif tedavi aldı. Üç olgu (\%13) ameliyat edildi. İki olgu (\%9) RKH sonucu hayatını kaybetti, 2 olgu da bir yıl içinde hastalık tekrarladı.

\section{SONUÇ}

Akut karın kliniğiyle gelen, yaşlı, öksüren ve antikoagülan tedavi alan hastalarda RKH den şüphelenilmelidir. Tercih edilen tanı şekli BT'dir. Erken tanı, morbiditeyi ve gereksiz cerrahi müdahaleyi önler.

Anahtar Sözcükler: Akut karın; antikoagulasyon; rektus kılıfı hematomu. 
Rectus sheath hematoma (RSH) is a rare complication of anticoagulation, which is often misdiagnosed as acute abdominal disorder and leads to a delay in diagnosis or unnecessary surgical intervention. ${ }^{[1-3]}$ The causes of RSH described in the literature include anticoagulant therapy, hematological disorders, trauma, physical exercise, coughing, sneezing, pregnancy, and hypertension..$^{[3-5]}$ The most common predisposing factor is anticoagulant therapy, and coughing has been implicated as the most important precipitating risk factor. ${ }^{[6]}$ Anticoagulant therapy is indicated for the prophylaxis of cardiac valve prosthesis, left ventricular dysfunction, and atrial fibrillation, and for the treatment of acute coronary syndrome, pulmonary embolism, deep vein thrombosis, and acute ischemic cerebrovascular disease. It has been the basic approach to initiate anticoagulant therapy with heparin followed by warfarin, but both require laboratory monitoring of dose. The risk of RSH may be increased in elderly patients with both impaired functional status and weakened rectus muscle, when coagulation parameters are uncontrolled. When RSH occurs, early recognition, diagnosis and treatment are necessary to minimize further complications including hemodynamic instability, abdominal compartment syndrome (ACS), multiorgan dysfunction, and death. ${ }^{[2,3,7]}$

The aging population and increased use of anticoagulant therapy without adequate control of coagulation parameters may cause a rise in the incidence of this condition. Because data about this relatively uncommon but life-threatening clinical entity are insufficient at present, we report a series of 22 patients with RSH.

\section{MATERIALS AND METHODS}

The records of 26 cases who were diagnosed clinically, radiologically or surgically as RSH in the Department of General Surgery of Mersin University Medical Faculty during the period September 2002 - August 2009 were reviewed retrospectively. Twentytwo spontaneous RSH patients who were on anticoagulation therapy without abdominal surgery within a few months were included in the study. Four patients with $\mathrm{RSH}$, including one caused after laparoscopic cholecystectomy, one after inguinal hernia repair and two after a traffic accident, were excluded from the study. Patient characteristics (age and sex), clinical characteristics and comorbidity, indications and form of anticoagulant therapy, number of anticoagulant therapy agents, laboratory tests (blood counts, platelet counts, activated partial thromboplastin time [APTZ] and international normalized ratio [INR]), medications, clinical presentation, radiological work-up (ultrasonography [US] or computerized tomography $[\mathrm{CT}]$ of the abdomen and pelvis), treatment modalities (surgery, conservative or blood transfusions), compli- cations, morbidity, mortality, and long-term follow-up results of the RSH patients were analyzed.

\section{RESULTS}

Twenty-two patients were treated in our clinic for spontaneous RSH caused by anticoagulation therapy. The study group consisted of 8 males (36\%) and 14 females (64\%), with a mean age of 60.6 years (range, 21-81 years). The patient characteristics are shown in Table 1.

All of the patients were receiving at least one form of anticoagulation therapy; 16 patients $(72 \%)$ were on warfarin, and 6 patients (28\%) were on low-molecular-weight heparin therapy.

The indications for anticoagulation therapy were atrial fibrillation or flutter with left ventricular dysfunction in 7 patients $(31.8 \%)$, cardiac valve replacement in 7 patients $(31.8 \%)$, acute deep vein thrombosis in 3 patients $(13.6 \%)$, ischemic cerebrovascular disease in 2 patients $(9.5 \%)$, documented or suspected pulmonary embolism in 1 patient $(4.5 \%)$, myocardial infarction in 1 patient $(4.5 \%)$, and left ventricular mural thrombus in 1 patient (4.5\%). Additionally, 14 patients $(63 \%)$ were receiving both anticoagulation and antiplatelet agents.

Fifteen patients (68\%) had comorbid conditions including diabetes mellitus $(\mathrm{n}=5)$, chronic lung disease $(\mathrm{n}=2)$, prior myocardial infarction $(\mathrm{n}=3)$, hypertension $(n=2)$, congestive heart failure $(n=2)$, Buerger's disease $(\mathrm{n}=1)$, and idiopathic dilated cardiomyopathy $(\mathrm{n}=1)$. History of coughing was found in 10 patients $(45 \%)$.

Seventeen (77\%) patients complained of abdominal mass and abdominal pain. Other presenting signs and symptoms of the patients included a decrease in hemoglobin of $0.4 \mathrm{~g} / \mathrm{dl}$ or greater $(\mathrm{n}=10,45 \%)$, nausea or vomiting $(\mathrm{n}=8,36 \%)$, abdominal wall ecchymosis $(n=5,22 \%)$, peritoneal irritation $(n=4,18 \%)$, fever $(\mathrm{n}=4,18 \%)$, and abdominal distension $(\mathrm{n}=2,9 \%)$.

For all of the patients on warfarin therapy, INR was found to be $>3.0(3.2-6.0)$.

The diagnosis was made by both abdominopelvic US and CT in 11 cases, by only CT in 3 cases, by only US in 6 cases, and by surgical exploration for acute abdomen in 2 cases. In 2 cases diagnosed during surgery, US had failed to show the RSH.

Blood transfusion and antibiotherapy were administered in all of the cases. In 11 patients, anticoagulant therapies were discontinued and intravenous vitamin $\mathrm{K}$ and fresh frozen plasma were administered. In 3 cases, bleeding was controlled during the operation.

Complications in $\mathrm{RSH}$ patients included hematoma infection $(n=2)$, deep vein thrombosis $(n=1)$, acute re- 
Table 1. Clinical and demographic characteristics of patients

\begin{tabular}{|c|c|c|c|c|c|c|c|c|}
\hline No & Age & Sex & $\begin{array}{c}\text { Anticoagulation } \\
\text { therapy }\end{array}$ & $\begin{array}{l}\text { Antiplatelet } \\
\text { agent }\end{array}$ & $\begin{array}{l}\text { Anticoagulation } \\
\text { indication }\end{array}$ & Comorbidity & Cough & INR \\
\hline 1 & 74 & Female & Warfarin & + & CVR & Chronic lung disease & + & 4.6 \\
\hline 2 & 51 & Female & Warfarin & - & $\mathrm{AF}+\mathrm{LVD}$ & MI & - & 5.3 \\
\hline 3 & 65 & Male & Warfarin & + & CVR & DM & - & 3.9 \\
\hline 4 & 21 & Female & Warfarin & + & $\mathrm{AF}$ & Idiopathic CMP & + & 4.2 \\
\hline 5 & 78 & Female & LMWH & - & Pulmonary embolism & $\mathrm{DM}$ & - & 1.2 \\
\hline 6 & 45 & Male & Warfarin & + & $\mathrm{AF}+\mathrm{LVD}$ & - & - & 4.8 \\
\hline 7 & 68 & Female & Warfarin & + & CVR & - & + & 6.0 \\
\hline 8 & 62 & Male & Warfarin & - & $\mathrm{AF}+\mathrm{LVD}$ & - & + & 3.2 \\
\hline 9 & 56 & Female & LMWH & - & Acute deep vein thrombosis & - & + & 1 \\
\hline 10 & 74 & Female & LMWH & + & $\mathrm{AF}+\mathrm{ICVD}$ & - & - & 0.9 \\
\hline 11 & 41 & Female & Warfarin & + & CVR & Hypertension & - & 4.4 \\
\hline 12 & 81 & Female & Warfarin & + & Left ventricular mural thrombosis & DM & + & 3.8 \\
\hline 13 & 67 & Male & LMWH & - & Acute deep vein thrombosis & - & - & 1.1 \\
\hline 14 & 63 & Male & Warfarin & - & $\mathrm{AF}+$ Mitral stenosis & - & + & 4.6 \\
\hline 15 & 56 & Female & Warfarin & + & CVR & Chronic lung disease & - & 4.0 \\
\hline 16 & 42 & Male & Warfarin & - & Acute deep vein thrombosis & Buerger disease & - & 3.8 \\
\hline 17 & 68 & Female & Warfarin & + & CVR & - & + & 4.8 \\
\hline 18 & 76 & Female & LMWH & + & ICVD & - & + & 1.0 \\
\hline 19 & 34 & Female & Warfarin & - & $\mathrm{AF}+\mathrm{LVD}$ & $\mathrm{DM}+\mathrm{MI}$ & - & $3 . .8$ \\
\hline 20 & 67 & Male & Warfarin & + & CVR & - & + & 4.2 \\
\hline 21 & 74 & Female & Warfarin & + & $\mathrm{AF}+\mathrm{LVD}$ & MI & - & 3.5 \\
\hline 22 & 71 & Male & LMWH & + & MI & DM + Hypertension & - & 1 \\
\hline
\end{tabular}

INR: International normalized ratio; LMWH: Low-molecular-weight heparin; CVR: Cardiac valve replacement; AF: Atrial fibrillation; LVD: Left ventricular dysfunction; ICVD: Ischemic cerebrovascular disease; CMP: Cardiomyopathy; DM: Diabetes mellitus; MI: Myocardial infarction.

nal failure $(n=1)$, and ileus of the bowel $(n=1)$. Two patients $(9 \%)$ died (1 treated surgically and 1 managed conservatively). The causes of deaths were acute respiratory distress syndrome and multiple organ failure. Two patients experienced recurrent $\mathrm{RSH}$ in the following year and were managed conservatively again. Diagnostic and treatment modalities and outcomes of the patients are given in Table 2.

\section{DISCUSSION}

Hemorrhagic complications are the most important adverse effects of anticoagulant therapy, and RSH is one of these complications that is commonly associated with anticoagulation. ${ }^{[4]}$

Adverse drug effects are more common among the geriatric population. ${ }^{[8]}$ The majority of patients are aged between 60 and 70 years. In our series, similarly, the mean age of patients with RSH caused by anticoagulation was 60.6 years. Elderly patients are more likely to be receiving anticoagulation therapy, and they also have impaired homeostatic reserve and functional status and use multiple medications. In addition, the rectus abdominis muscle becomes weakened with inactivity and aging that results in increased vascularity of the abdominal wall.

RSH occurs more frequently in women than in men, and it demonstrates a male: female ratio of 1 :
$2-3 \cdot{ }^{[4,5,9]}$ Concordant with the previous reports, the male to female ratio was in favor of females in our series. One possible reason for the sex difference is the disparity in the size, shape and tone of the rectus

Table 2. Diagnostic and treatment modalities and outcomes

\begin{tabular}{lclcc}
\hline No & $\begin{array}{c}\text { Diagnostic } \\
\text { modalitiy }\end{array}$ & Management & Complication & Recurrence \\
\hline 1 & US, CT & Conservative & & \\
2 & US & Conservative & & - \\
3 & CT & Conservative & Deep vein thrombosis & - \\
4 & US & Conservative & & - \\
5 & Surgical & Surgery & Death & - \\
6 & CT & Conservative & & - \\
7 & US, CT & Conservative & Hematoma infection & - \\
8 & Surgical & Surgery & & - \\
9 & US & Conservative & & - \\
10 & US, CT & Conservative & Ileus & - \\
11 & US, CT & Conservative & & + \\
12 & CT & Conservative & & - \\
13 & US, CT & Conservative & Acute renal failure & - \\
14 & US & Conservative & & - \\
15 & US, CT & Conservative & & - \\
16 & US & Conservative & & - \\
17 & US, CT & Conservative & Hematoma infection & - \\
18 & US, CT & Conservative & Death & - \\
19 & US, CT & Conservative & & - \\
20 & US & Conservative & & - \\
21 & US, CT & Surgery & & - \\
22 & US, CT & Conservative & & \\
\hline & & & & \\
\hline
\end{tabular}


muscle. Men have a larger rectus muscle and this may provide protection against trauma to the muscle.

In the pathophysiology of RSH, there is an accumulation of blood in the sheath of the rectus abdominis muscle, secondary to either epigastric vessel tear or direct rupture of the rectus muscle's fibers. The anatomical feature predisposes to vessel rupture with accumulation of large hematomas. ${ }^{[10]}$

The classical clinical description of RSH includes sudden onset of abdominal pain that is often associated with nausea, fever and vomiting. Patients may present with Fothergill's sign including a painful, palpable mass in the abdominal wall that does not cross the midline. ${ }^{[11]}$ In our series, the most common presenting sign or symptom was abdominal pain and mass, followed by a decrease in hemoglobin of $0.4 \mathrm{~g} /$ $\mathrm{dl}$ or greater. Abdominal wall ecchymosis, peritoneal irritation, fever, and abdominal distension were less common presenting signs and symptoms. Laboratory findings may demonstrate a decrease in the hemoglobin level, although this may be misleading early in the course. Leukocytosis, thrombocytosis and prolonged clotting studies in patients on oral anticoagulation may also be present. Patients on warfarin must be under close monitoring of INR. In other studies, patients with INR level $>3$ showed a 5 -times increased risk of hemorrhagic complication. In addition, hypertension and renal or cerebrovascular diseases significantly increase the bleeding risk. In our series, the INR levels of all patients on warfarin therapy were $>3$.

Both US and CT are the diagnostic modalities of choice. US has sensitivity ranging from $70 \%$ to $90 \%$ in published reviews, while CT has 100\% sensitivity and specificity for RSH in many series. ${ }^{[5,12-14]}$ Both methods are useful for differentiating intra-abdominal pathologies and reducing unnecessary laparotomy. On the other hand, CT is the gold standard diagnostic modality, because most of these patients are elderly cardiac patients, and several acute abdominal conditions including mesenteric ischemia, rupture of an abdominal aneurysm, peptic ulcer disease, and perforation secondary to aspirin must be excluded. CT can also show whether the bleeding is active or not. Although CT successfully showed RSH in 14 of our patients with $100 \%$ sensitivity, US failed to show RSH in 2 patients.

Conservative methods should be used primarily in the treatment of RSH. Conservative methods consist of bed rest, analgesia, intravenous fluid resuscitation, ice pack application, compression, blood transfusions, and correction of coagulopathy. In patients with high risk of thromboembolic events, when the bleeding is under control, heparin and warfarin therapy must be started, synchronized with INR follow-up. When INR reaches the desired level, heparin is discontinued.
In the study by Cherry et al., ${ }^{[3]}$ only $4.8 \%$ of the patients had a repeat episode of RSH after the anticoagulation therapy was restarted. Reinitiating anticoagulation was shown to be safe in high-risk patients for thromboembolic events. Two out of 22 patients had a repeat episode of RSH in our series after anticoagulation therapy was restarted.

Surgical intervention should be considered when conservative treatment fails and would be indicated when hemodynamic stability cannot be achieved. When active bleeding is identified, patients can be managed with catheter-based arterial embolization, by radiologically guided drainage or by laparotomy with vessel ligation and evacuation of the hematoma. ${ }^{[2,3,5,15]}$ Although the surgical treatment of patients with larger RSH due to anticoagulation therapy is associated with shorter hospital stay and less need for analgesics, patients may also develop abdominal hypertension that may progress to ACS and an increased risk of significant morbidity or death. ${ }^{[16]}$ With early diagnosis and conservative management, surgical intervention can be avoided even with large hematomas.

RSH can lead to serious complications including infection, acute renal failure, myocardial infarction, hypovolemic shock, myonecrosis, ACS, small bowel infarction, and death. ${ }^{[2,3,14,17]}$ In our series, hematoma infection, deep vein thrombosis, acute renal failure, and ileus were the complications of RSH that were treated conservatively. The overall mortality in patients with RSH has been reported to be $4 \%$. The mortality is higher $(25 \%)$ in patients undergoing anticoagulation therapy, whereas mortality rates in iatrogenic RSH and pregnant patients are $18 \%$ and $13 \%$, respectively. ${ }^{[10]}$ In our series, the causes of the two deaths $(9 \%)$ were acute respiratory distress syndrome and multiple organ failure.

In conclusion, the diagnosis of RSH should always be considered in elderly, especially female, coughing patients on anticoagulation therapy, who present with clinical manifestations of acute abdomen, a palpable abdominal mass and anemia. CT of the abdomen and pelvis is the diagnostic modality of choice. Early diagnosis is important to avoid increased morbidity or unnecessary surgical intervention. Treatment is mainly conservative with pain management, antibiotherapy and blood transfusions. Surgery may be needed in cases when hemodynamic stability cannot be achieved. In addition, we advise that all patients on anticoagulation therapy should be under laboratory monitoring.

\section{REFERENCES}

1. Miyauchi T, Ishikawa M, Miki H. Rectus sheath hematoma in an elderly woman under anti-coagulant therapy. J Med Invest 2001;48:216-20.

2. Zainea GG, Jordan F. Rectus sheath hematomas: their pathogenesis, diagnosis, and management. Am Surg 1988;54:630-3. 
3. Cherry WB, Mueller PS. Rectus sheath hematoma: review of 126 cases at a single institution. Medicine (Baltimore) 2006;85:105-10.

4. Denard PJ, Fetter JC, Zacharski LR. Rectus sheath hematoma complicating low-molecular weight heparin therapy. Int J Lab Hematol 2007;29:190-4.

5. Berná JD, Zuazu I, Madrigal M, García-Medina V, Fernández C, Guirado F. Conservative treatment of large rectus sheath hematoma in patients undergoing anticoagulant therapy. Abdom Imaging 2000;25:230-4.

6. Fukuda T, Sakamoto I, Kohzaki S, Uetani M, Mori M, Fujimoto T, et al. Spontaneous rectus sheath hematomas: clinical and radiological features. Abdom Imaging 1996;21:58-61.

7. Osinbowale O, Bartholomew JR. Rectus sheath hematoma. Vasc Med 2008;13:275-9.

8. Arai H, Akishita M, Teramoto S, Arai H, Mizukami K, Morimoto $\mathrm{S}$, et al. Incidence of adverse drug reactions in geriatric units of university hospitals. Geriatr Gerontol Int 2005;5:293-7.

9. Luhmann A, Williams EV. Rectus sheath hematoma: a series of unfortunate events. World J Surg 2006;30:2050-5.

10. Hildreth DH. Anticoagulant therapy and rectus sheath hematoma. Am J Surg 1972;124:80-6.
11. Fothergill WE. Haematoma in the Abdominal Wall Simulating Pelvic New Growth. Br Med J 1926;1:941-2.

12. Moreno Gallego A, Aguayo JL, Flores B, Soria T, Hernández Q, Ortiz S, et al. Ultrasonography and computed tomography reduce unnecessary surgery in abdominal rectus sheath haematoma. Br J Surg 1997;84:1295-7.

13. Berná JD, Garcia-Medina V, Guirao J, Garcia-Medina J. Rectus sheath hematoma: diagnostic classification by CT. Abdom Imaging 1996;21:62-4.

14. Khan MI, Medhat O, Popescu O, Rastogi A, Thompson T. Rectus sheath haematoma presenting as acute abdomen. ANZ J Surg 2005;75:502-3.

15. Rimola J, Perendreu J, Falcó J, Fortuño JR, Massuet A, Branera J. Percutaneous arterial embolization in the management of rectus sheath hematoma. AJR Am J Roentgenol 2007; 188:W497-502.

16. O’Mara MS, Semins H, Hathaway D, Caushaj PF. Abdominal compartment syndrome as a consequence of rectus sheath hematoma. Am Surg 2003;69:975-7.

17. Dineen RA, Lewis NR, Altaf N. Small bowel infarction complicating rectus sheath haematoma in an anticoagulated patient. Med Sci Monit 2005;11:CS57-9. 